Portland State University

PDXScholar

$1-1-1998$

\title{
Genetic Markers in Plant Evolutionary Ecology
}

Mitchell B. Cruzan

Portland State University

Follow this and additional works at: https://pdxscholar.library.pdx.edu/bio_fac

Part of the Plant Biology Commons, and the Plant Breeding and Genetics Commons Let us know how access to this document benefits you.

\section{Citation Details}

Cruzan, M. B. (1998). Genetic markers in plant evolutionary ecology. Ecology, 79(2), 400-412.

This Article is brought to you for free and open access. It has been accepted for inclusion in Biology Faculty Publications and Presentations by an authorized administrator of PDXScholar. Please contact us if we can make this document more accessible: pdxscholar@pdx.edu. 


\title{
GENETIC MARKERS IN PLANT EVOLUTIONARY ECOLOGY
}

\author{
Mitchell B. CRUZAN \\ Department of Ecology and Evolutionary Biology, Department of Botany, University of Tennessee, \\ Knoxville, Tennessee 37996 USA
}

\begin{abstract}
Genetic markers have provided plant ecologists with a method of assessing levels of genetic relatedness among individuals and populations. In recent years a number of techniques based on DNA sequence variation have been developed to complement allozyme methods that are already widely used. Some of these new markers are more variable than protein-based markers, allowing more precise estimates of genetic differences among individuals and populations. Other DNA-based markers are based on organelle genomes that are inherited uniparentally. These cytoplasmic markers can provide a method for assessing the separate effects of seed and pollen dispersal on gene flow within and among populations and species. Studies of hybrid populations have been facilitated by the development of inferential techniques for assessing levels of selection and patterns of introgression between species. Genetic markers have also been used to describe mating patterns within populations and to examine the ecological and genetic mechanisms that contribute to variation in selfing and reproductive success. Integration of ecological methods with genetic marker techniques continues to provide novel approaches to the study of evolutionary processes in plant populations.
\end{abstract}

Key words: cytonuclear disequilibria; cytoplasmic DNA markers; ecological genetics; genetic markers; hybridization; molecular markers; paternity analysis; plant mating system.

\section{INTRODUCTION}

Genetic markers have contributed to the study of plant evolutionary ecology by providing methods for detecting genetic differences among individuals. Several early investigations in plant population biology utilized genetic polymorphisms that were controlled by a single locus. Although these morphological genetic markers proved useful in several cases (e.g., Epling and Dobzhansky 1942, Fabergé 1943), this approach has obvious limitations because (1) morphological variants are not available for most species, (2) studies utilizing morphological characters are generally limited to only one locus, and (3) many characters (e.g., flower color) have to be scored relatively late in the life cycle. While early studies of genetic variation with morphological characters were relatively few, the establishment of new marker techniques has facilitated a burgeoning of research in plant ecological genetics.

The study of genetic variation in plant populations was greatly facilitated by the development of proteinbased markers (i.e., allozymes) over three decades ago (reviewed in Loveless and Hamrick 1984, Hamrick and Godt 1990). The primary contribution of allozymes to plant population biology has come from their utilization as neutral (or nearly neutral) genetic markers. Al-

Manuscript received 15 July 1995; revised and accepted 14 October 1996; final version received 27 May 1997. For reprints of this Special Feature, see footnote 1, p. 359. lozymes have been employed to characterize patterns of genetic variation within and among populations, and to examine the processes of dispersal and the patterns of mating that influence levels of genetic differentiation (Brown 1979, Loveless and Hamrick 1984, Hamrick and Godt 1990, Barrett and Kohn 1991). These studies have contributed an evolutionary dimension to our understanding of contemporary ecological processes. Allozyme markers remain the most useful tool for addressing many questions in plant population biology, yet the development of numerous DNA markers in recent years (reviewed in Avise 1994) may provide opportunities to address questions that were not previously feasible, as described further below.

Plants offer both unique challenges and opportunities for the study of ecological genetics. With the exception of a few aquatic species, plants are sedentary over most of their life history, so the genetic composition of mature individuals may reflect selection on early stages by local microenvironments. From a population-genetic standpoint, this lack of mobility combined with limited pollen and seed dispersal is expected to contribute to a high degree of genetic structure, resulting in a population that consists of groups of closely related individuals. This process can be intensified by varying levels of self-compatibility in hermaphroditic species, contributing to local inbreeding and the generation of highly homozygous offspring. Local mating in plant populations may provide an opportunity for selection 
to affect the genetic composition of populations; however, this process will be counterbalanced by gene dispersal, which may erase any genetic changes that result from local selection or drift. Hence, understanding both genetic and ecological processes is critical for assessing levels of genetic differentiation and the potential influence of natural selection on morphological and physiological characters.

Here I attempt to highlight some of the more recent advances for the application of genetic markers to questions in plant population biology. These include new techniques that utilize allozyme markers as well as applications for DNA-based markers. Specifically I endeavor to put population genetic studies into an ecological context. In doing so I hope to point out conceptual intersections where the further application of genetic markers will enhance our understanding of ecological processes.

\section{Mating in Plant Populations: Patterns And MeChanisms}

Mating events in plants are governed by the behavior of pollen vectors and by processes affecting post-pollination siring success. Animal pollinators typically deposit pollen loads consisting of mixtures of self pollen and outcross pollen from several donors (Thomson and Plowright 1980, Waser and Price 1982, Thomson and Stratton 1985, Thomson et al. 1986, Thomson and Thomson 1989). With similar siring abilities of all pollen types, the delivery of mixed pollen loads will result in the production of both selfed and outcrossed seeds (i.e., mixed mating: Schemske and Lande 1985, Barrett and Eckert 1990). Outcrossed seeds within a fruit may be sired primarily by one or a few donors (correlated mating: Ritland 1989), or may be more representative of all available pollen donors. Furthermore, the success of individual outcross donors may not reflect the frequency of their pollen in the stigma load (Cruzan 1990b, Snow and Spira 1991, Marshall and Folsom 1992, Cruzan and Barrett 1993). The genetic composition of the seeds produced will ultimately depend on the composition of pollen loads and the action of a number of postpollination processes. Genetic markers have provided us with insights into both the patterns of mating occurring in plant populations and the preand postpollination mechanisms that contribute to those patterns.

Paternity analysis. - One approach to the description of mating patterns in plant populations attempts to identify the paternal parent of seeds collected from known maternal plants (reviewed in Snow and Lewis 1993). Two procedures have been used: (1) identification of the only possible or most probable father by matching multilocus genotypes (Meagher 1986, Broyles and Wyatt 1990), and (2) using the cumulative probabilities of paternity for all seeds scored from maximum likelihood procedures to determine the reproduc- tive success of each pollen donor (i.e., fractional paternity; Devlin et al. 1988). Attempts to unambiguously determine paternity with allozyme markers have had limited success because assignments can generally be made to only a minority of the seeds produced (Snow and Lewis 1993). With fractional paternity a larger proportion of data generated can be used for statistical analyses (Devlin and Ellstrand 1990, Devlin et al. 1992). Multi-allelic markers (e.g., microsatellites) could increase the power of these procedures, but such experiments require a significant amount of effort and are probably best applied to relatively small populations (Snow and Lewis 1993).

Most studies using paternity determination procedures have been able to identify substantial variation in male reproductive success and correlations between success and other variables examined (reviewed in Snow and Lewis 1993). For example, male fertility rose with plant size in some studies (Schoen and Stewart 1987, Broyles and Wyatt 1990, Devlin et al. 1992), and significant variation in functional gender has also been noted (i.e., relative level of male and female reproductive success within individuals; Devlin and Ellstrand 1990). A variety of morphological and population density variables affected male reproductive success in a study of Raphanus sativus (Devlin and Ellstrand 1990), however, significant components of unexplained variation in male success were found in this and other cases (e.g., Meagher 1986). Further studies exploring the effects of variation in morphological, physiological, and phenological traits on male fertility hold promise for shedding light on a variety of questions in plant reproductive ecology.

Mating system estimation.-An alternative approach to the study of plant mating uses classifications of mating events to characterize levels of inbreeding and patterns of gene dispersal in populations. These mating system studies usually endeavor to estimate frequencies of selfing and outcrossing (reviewed in Schemske and Lande 1985, Barrett and Eckert 1990, Brown, 1990), but can also include other categories (e.g., intermorph mating in heterostylous species-Barrett et al. 1987, Kohn and Barrett 1992a; or levels of biparental inbreeding-Ritland 1984, Brown 1990). Estimates of selfing frequency can be derived from the genotypes of progeny at a number of developmental stages (seeds, seedlings, or adult offspring). Since selfed progeny may not always survive early stages of development (e.g., Wiens et al. 1987), assaying later stages may underestimate the selfing frequency and its impact on the fitness of individuals (Husband and Schemske 1996).

A variety of genetic markers have been used to estimate selfing frequencies, including morphological characters (Vasek 1964; Harding et al. 1974, Humphreys and Gale 1974, Rick et al. 1978, Motten and Antonovics 1992), allozymes (Ritland and Ganders 
1985, Schemske and Lande 1985, Barrett and Eckert 1990, Brown 1990), and RAPDs (randomly amplified polymorphic DNA: Fritsch and Rieseberg 1992, Cruzan and Arnold 1994). The latter technique has the disadvantage of dominant expression of banding phenotypes (i.e., heterozygous individuals cannot be discriminated), but the reduced amount of information provided by each locus can be compensated by utilizing larger numbers of loci. While allozymes remain the most widely used technique for mating system estimation, microsatellite markers may be an attractive alternative due to their high levels of allelic variation and codominant expression.

Analyses of mating system variation have been greatly facilitated by development of a number of procedures for the estimation of selfing frequency in populations (Fyfe and Bailey 1951, Ritland and Jain 1981, Brown 1990, Ritland 1990). These mixed-mating models assume random siring of outcrossed progeny, but models based on a number of other mating schemes have also been developed (e.g., one pollen parentSchoen 1988; or varying levels of sibship among progeny-Ritland 1989). Analysis of selfing and outcrossing in plant populations has been the focus of these procedures for several reasons: (1) selfing increases homozygosity to a much greater extent than other modes of inbreeding (Charlesworth and Charlesworth 1987), and hence will have a large impact on levels of gene flow and the evolution of genetic load (Lande et al. 1994); and (2) empirical evidence on patterns of mating-system variation has been crucial to our understanding of the evolution of selfing (Lloyd 1979, 1992, Holsinger 1991, Uyenoyama et al. 1993). The application of procedures for the estimation of selfing and outcrossing frequencies has produced a large database on mating-system variation in plants (reviewed in Schemske and Lande 1985, Barrett and Eckert 1990, Brown 1990).

Comparisons of mating patterns across species and populations have revealed associations between outcrossing frequency and life history parameters, levels of inbreeding depression, and pollination syndromes (reviewed in Barrett and Eckert 1990). Intraspecific surveys of mating system variation among populations have demonstrated associations between levels of outcrossing and a variety of demographic and genetic factors including flower color (Horovitz and Harding 1972), degree of dichogamy (i.e., temporal separation of sexual function within flowers [Vasek and Harding 1976, Schoen 1982]), plant density (Farris and Mitton 1984, Wolff et al. 1988), population structure (Ritland and Ganders 1985), and variation in pollinator abundance (Horovitz and Harding 1972).

Mating system variation within populations.-Less information is available on variation in mating patterns among individuals in a population. Variation in frequencies of outcrossing among plants can be parti- tioned into its ecological (i.e., due to differences in pollinator activity and behavior, population density, and environmental factors) and genetic (i.e., morphological and physiological) components. Recently Lloyd and Schoen (Lloyd 1992, Lloyd and Schoen 1992, Schoen and Lloyd 1992) emphasized that studies of these mechanisms are needed to increase our understanding of selection for reproductive assurance and for different selfing modes. Examination of these fundamental aspects of plant mating has become increasingly important as recent theoretical treatments of the evolution of selfing (Holsinger 1991, Lloyd 1992, Uyenoyama et al. 1993) and empirical analyses (Piper et al. 1986, Barrett and Eckert 1990, Motten and Antonovics 1992, Cruzan et al. 1994) have made it clear that ecological factors are often important for the maintenance of mixed mating.

Studies of the influence of ecological and genetic mechanisms on patterns of selfing and outcrossing within plant populations have been hampered by a lack of precise techniques for the estimation of flower-level outcrossing frequencies. Errors associated with singlefruit estimates using the multilocus outcrossing (MLT) procedure of Ritland and Jain (1981) can be relatively large (Ritland and Ganders 1985), and this method often fails to yield reasonable estimates for all fruits (i.e., because of small sample sizes or departures from random outcrossing: Morgan and Barrett 1990, Cruzan et al. 1994). These problems can be alleviated by dividing fruits into treatment groups (MLT2 procedure of Ritland 1990, Leclerc-Potvin and Ritland 1994), or by using simplifying assumptions to obtain less accurate estimates (e.g., Humphreys and Gale 1974, Morgan and Barrett 1990, Motten and Antonovics 1992). One recently developed procedure uses information on maternal genotypes to produce relatively accurate outcrossing estimates for each fruit (Cruzan et al. 1994).

Substantial amounts of variation in outcrossing frequency can be found among plants and among flowers on the same plant (Leclerc-Potvin and Ritland 1994; Table 1). Studies have demonstrated that mating systems are influenced by variables such as levels of population structure and density (Ennos and Clegg 1982, Ellstrand and Foster 1983, Karron et al. 1995; Table 1 ), and variation in floral morphology (Kohn and Barrett 1992a; Table 1). Studies of factors affecting outcrossing frequency in natural populations (Cruzan et al. 1994), and experiments that combine manipulations of flowers with mating system estimation (Kohn and Barrett 1992b, Leclerc-Potvin and Ritland 1994) will further our understanding of mating system variation and the role of reproductive assurance in the maintenance of mixed mating.

Characterization of postpollination processes.Processes occurring after pollination can also affect mating patterns. Variation in pollen-tube growth and nonrandom abortion of developing zygotes have tra- 
TABLE 1. Variation in family-level outcrossing estimates and effects of environmental factors (population density) and variation in floral morphology $(+=$ significant effect found; $-=$ no effect detected; nt $=$ not tested $)$ on outcrossing frequency reported in published studies. Information on marker type $(\mathrm{A}=$ allozymes, $\mathrm{M}=$ morphological $)$ is given as well as method of estimation ( $t_{\mathrm{ml}}=$ maximum likelihood method of Ritland and Jain [1981]; $t=$ other estimation methods).

\begin{tabular}{|c|c|c|c|c|c|c|}
\hline \multirow[b]{2}{*}{ Species } & \multirow{2}{*}{$\begin{array}{l}\text { Range in } \\
\text { outcrossing } \\
\text { frequency }\end{array}$} & \multirow[b]{2}{*}{ Marker } & \multirow[b]{2}{*}{ Method } & \multicolumn{2}{|c|}{ Factors } & \multirow[b]{2}{*}{ Source } \\
\hline & & & & Env. & Floral & \\
\hline Bidens menziesii & $0.00-1.00$ & A & $t_{\mathrm{ml}}$ & nt & $\mathrm{nt}$ & Ritland and Ganders 1985 \\
\hline Carduus mutans $\dagger$ & $0.00-0.80$ & A & $t$ & - & $\mathrm{nt}$ & Smyth and Hamrick 1984 \\
\hline Clarkia exilis $\ddagger$ & $0.04-0.70$ & M & $t$ & nt & $\mathrm{nt}$ & Vasek 1964 \\
\hline Datura stramonium & $0.02-0.19$ & M & $t$ & + & + & Motten and Antonovics 1992 \\
\hline \multirow[t]{2}{*}{ Eichhornia paniculata } & $0.39-1.35$ & A & $t_{\mathrm{ml}}$ & nt & $\mathrm{nt}$ & Morgan and Barrett 1990 \\
\hline & $0.17-0.98$ & A & $t$ & nt & nt & Morgan and Barrett 1990 \\
\hline Ipomoea purpurea & $0.44-0.87$ & A & $t$ & nt & + & Brown and Clegg 1984 \\
\hline Iris fulva & $0.00-1.00$ & A & $t$ & + & nt & Cruzan et al. 1994 \\
\hline Iris hexagona & $0.00-1.00$ & A & $t$ & + & nt & Curzan et al. 1994 \\
\hline \multicolumn{7}{|l|}{ Lycopersicon pimpinelli- } \\
\hline folium & $0.00-0.84$ & M & $t$ & nt & + & Rick et al. 1978 \\
\hline Lupinus nanus & $0.08-0.84$ & M & $t$ & nt & nt & Harding et al. 1974 \\
\hline Malva moschata & $0.06-0.74$ & A & $t$ & + & nt & Crawford 1984 \\
\hline Mimulus ringens & $0.10-0.35$ & A & $t$ & + & $\mathrm{nt}$ & Karron et al. 1995 \\
\hline Papaver dubium & $0.07-0.68$ & M & $t$ & + & nt & Humphreys and Gale 1974 \\
\hline
\end{tabular}

$\dagger$ Estimates for only six isolated plants.

\$ One-meter square plots rather than individual plants.

ditionally been analyzed by direct observation; however, this approach tends to be unsatisfactory for population studies because (1) the performance of only one pollen donor within a flower can generally be observed (but see Aizen et al. 1990, Cruzan 1990a), and (2) progress of growth or abortion is halted, providing only a single snapshot of an ongoing process. Genetic markers allow the use of mixtures of pollen so that the siring ability of individual pollen types can be assessed under conditions that more closely mimic natural pollination.

Controlled pollinations with mixtures of genetically marked pollen have been used in several studies to infer differences in pollen growth. In most reports, outcross pollen has had a consistent seed-siring advantage over self pollen (Pfahler 1967, Weller and Ornduff 1977, Bowman 1987, Cruzan and Barrett 1993, Jones 1994), but cases where self pollen had a greater seed-siring ability have also been found (Snow and Spira 1991, Johnston 1993, Snow and Spira 1993). These siring advantages are generally attributed to differences in pollen-tube growth rate; however, without manipulations of the number of pollen grains used in pollinations (Cruzan and Barrett 1996), analyses of fertilizations at different distances from the stigma (e.g., in maizePfahler 1967), or observations of siring ability after different time delays between the application of pollen types (see Fig. 1), it is difficult to separate the effects of growth rate from differential failure of pollen or abortion of ovules. Application of inferential techniques that use genetic markers in combination with controlled crosses will provide insights into the postpollination mechanisms contributing to mating-system variation.

Studies of postfertilization processes using genetic markers are less common. Combining information on patterns of ovule abortion in single- and multiple-donor crosses with the siring ability of individual donors can provide clues about the contribution of postfertilization abortion to differential siring success (Casper 1988, Montalvo 1992, Baker and Shore 1995). In an alternative approach to the detection of differential ovule abortion, a time interval is allowed to pass between application of two different pollen types (i.e., pollen precedence experiments: Epperson and Clegg 1987, Rigney et al. 1993). Analysis of siring success over a series of increasing time delays with the disadvantaged pollen applied first could potentially separate the effects of differential pollen-tube growth rate, pollentube attrition, and zygote abortion (Fig. 1). Given the power and simplicity of these genetic marker studies, they are likely to continue to make substantial contributions to our understanding of postpollination mechanisms.

More direct observation of postfertilization abortion patterns with genetic markers is also possible. For example, in an elegant experiment on ovule abortion patterns in Erythronium grandiflorum, Rigney (1995) removed sections of the ovary wall and observed the growth of individual ovules after pollination with mixtures of marked pollen. This technique allowed her to excise ovules as they showed signs of aborting, and to use allozyme assays to demonstrate that the majority of the aborted ovules had been fertilized by self pollen. One drawback to using allozyme markers comes as a result of a lack of expression of paternal enzymes in the earliest stages of embryo development (Rigney 1995). A solution to this difficulty would be to use DNA-based markers that use PCR (i.e., the polymerase chain reaction: RAPDs [random amplified polymorphic DNA] or microsatellites). These techniques, which can 


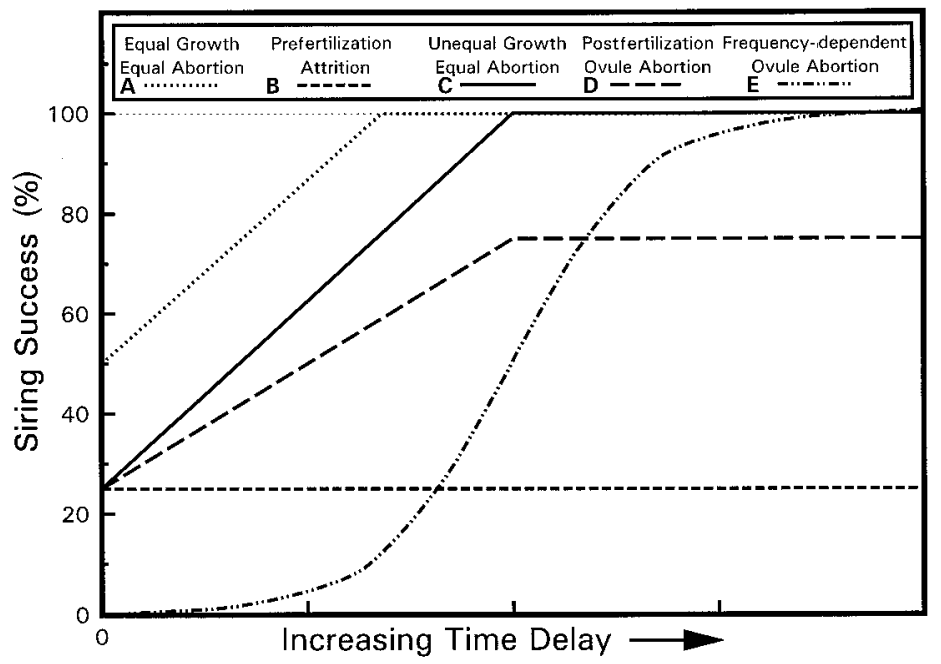

FIG. 1. Expected patterns of siring success for self pollen applied to stigmas before outcross pollen with an increasing time delay between pollinations. (A) Both pollen types equal; (B) siring disadvantage due to higher rates of prefertilization attrition of pollen tubes; (C) disadvantage due to differences in pollen-tube growth rates; (D) disadvantage due to a higher frequency of ovule abortion; and (E) most self ovules abort unless their frequency is above some threshold.

amplify markers from relatively small amounts DNA (e.g., from single pollen grains [D. Taylor, personal communication] or ovules early in development [M. B. Cruzan, unpublished data]), appear to be particularly suitable for detailed studies of pollen-tube growth and postfertilization ovule abortion.

\section{Genetic relatedness within and among populations}

The widespread use of allozyme techniques that began in the late 1960s has produced a large volume of data on genetic variation in plant species. Patterns across a broad range of taxa are mostly consistent with our understanding of the effects of breeding systems (selfing species tend to possess lower levels of genetic variation within populations), life history (longer lived perennials tend to be more variable), and geographic range (endemic taxa tend to be less variable) on the distribution of genetic diversity within and among populations (reviewed in Hamrick et al. 1979, Loveless and Hamrick 1984, Nevo et al. 1984, Hamrick and Godt 1990).

While allozyme markers are likely to continue to be the primary tool for population structure analyses, studies using DNA markers have begun to contribute to this database. For example, estimates of levels of genetic diversity and degrees of structuring among plant populations have been made using minisatellite fingerprinting (Wolff et al. 1994), RAPDs (Dawson et al. 1993, Russell et al. 1993), restriction site and length variation in ribosomal DNA (rDNA: Learn and Schaal 1987, Schaal and Learn 1988, King and Schaal 1989, Capossela et al. 1992), and restriction site variation in chloroplast DNA (cpDNA: Milligan 1991, Hong et al. 1993). Estimates of genetic differentiation among populations (e.g., $F_{\text {st }}$, Wright 1978) can be obtained from levels of band sharing among individuals (e.g., for rDNA and minisatellite techniques: Davis et al. 1990, Lynch and Milligan 1994). Such estimates appear to closely reflect patterns found with $F_{\text {st }}$ values derived from allozyme markers (Davis et al. 1990, Wolff et al. 1994). Calculation of levels of genetic differentiation among populations is more direct for cpDNA markers (Nei 1975, Weir 1990, Milligan 1991), but can be problematic for dominant RAPD markers (Lynch and Milligan 1994). More precise estimates of $F_{\text {st }}$ from RAPD markers can be obtained if only loci having low frequencies of the band phenotype are chosen (Lynch and Milligan 1994), or if only loci expressing codominant allelic variation are used (up to $10 \%$ of the markers found in some studies: Hunt and Page 1992, Cruzan and Arnold 1994).

While several of the abovementioned techniques can provide information about levels of genetic relatedness, these approaches are not ideal for characterizing levels of genetic structure within and between populations. Markers that represent Mendelian loci and have codominant expression are required for the generation of standard estimates of genetic diversity and gene flow (i.e., $F$ statistics: Wright 1978). Several of the available DNA techniques (e.g., rDNA, minisatellites) lack clear allelism (i.e., bands cannot be assigned to a particular locus), and with most RAPD markers, loci can clearly be identified but heterozygous genotypes cannot be discriminated. Because allozymes are relatively easy to assay they remain the marker of choice for population genetic studies, however when insufficient variation is detected with this technique, microsatellites are a viable alternative (i.e., bands are allelic and heterozygotes can be identified).

Genetic diversity in clonal species.-Asexual reproduction is relatively common in plant species (Fryxell 1957) and can occur through a number of modes (e.g., vegetative spread, production of vegetative propagules, or apomixis) to produce varying distributions of identical genotypes within and among populations (reviewed in Ellstrand and Roose 1987). One difficulty 
with the study of genotypic diversity in clonal species has been the inadequacy of allozyme markers to reliably identify all genotypes present. Hence, all individuals may not be separated (e.g., Mashburn et al. 1978), and the number of genotypes identified tends to increase when more polymorphic markers are used (Ellstrand and Roose 1987). These problems have been alleviated in recent studies by employing hypervariable DNA-based markers, including VNTR (variable number of tandem repeats: Nybom et al. 1990, Nybom and Schaal 1990, Rogstad et al. 1991a, $b$; also known as minisatellite markers), and RAPD (Wilde et al. 1992, Russell et al. 1993, Hsian and Rieseberg 1994) technologies. The studies conducted thus far have been somewhat limited in scope, but this approach holds considerable promise for the assessment of genetic diversity in clonal taxa.

Genetic markers have been used in clonal species to discriminate among sexually derived clones within a population. The utility of a DNA marker for this purpose will depend on the rate of sexual reproduction relative to rates of somatic mutation (Brookfield 1992). Although higher frequencies of sexual reproduction can apparently lead to increased genetic diversity among clones (Ellstrand and Roose 1987, Nybom and Schaal 1990), in practice it is difficult to distinguish somatic mutation events at marker loci from sexual reproduction events (e.g., Hsian and Rieseberg 1994). One approach to estimating somatic mutation rates would be to assay separate cell lines within plants (Poethig 1987) by taking multiple samples from the same individual (Schaal 1987). Sampling within and among individuals and assaying for variation in hypervariable markers may allow more precise estimates of genetic diversity and rates of sexual and asexual reproduction in plant populations.

Estimation of heritability in the field.-Knowledge of the narrow-sense heritability of quantitative characters $\left(h^{2}\right.$; Falconer 1981) is necessary for predicting short-term responses to selection. Obtaining values for the heritability of characters is generally an involved process, requiring comparisons across generations or among family groups of known lineage that have been grown in a uniform environment (Falconer 1981). These requirements have made it difficult, if not impossible, to estimate the heritability of characters in many plant taxa that are either long lived or difficult to cultivate. Recently, however, Ritland (Ritland 1996, Ritland and Ritland 1996) has developed estimation procedures that use genetic marker and quantitative trait data to infer the heritability of characters by sampling plants under field conditions. These methods use genetic marker data and the spatial structure of populations to separate the effects of relatedness and environmental influences on character similarities among individuals (Ritland 1996). The further development and application of these estimation procedures will pro- vide ecologists with an invaluable tool for understanding the evolutionary implications of variation in morphological and physiological characters.

Gene dispersal via pollen and seeds.-Gene flow in hermaphroditic plant species occurs through a combination of pollen and seed dispersal. Seeds move genetic material solely as a result of their physical displacement from the maternal plant, while the contribution of pollen to gene dispersal will be affected by pollen movement, seed dispersal, and the frequency of selfing (Ennos 1994). While paternity analyses can be used to estimate effective gene dispersal via pollen alone (e.g., Meagher 1986, Adams et al. 1992, Stacey et al. 1996), characterization of processes contributing to the distribution of genetic variation requires analysis of the separate effects of seeds and pollen on gene movement. Genetic markers that are based on the genomes of maternally inherited organelles can be developed, providing a convenient means of tracking seed dispersal within and among populations. By contrasting the distribution of these uniparentally inherited cytoplasmic markers with biparentally inherited nuclear markers, estimates of the relative contribution of pollen dispersal, seed dispersal, and the breeding system to patterns of genetic variation can be obtained (Ennos 1994, McCauley 1994).

Cytoplasmic DNA markers can be developed by conducting restriction enzyme digests of whole-organelle genomes (Banks and Birky 1985, Dong and Wagner 1993, 1994), or by amplifying specific regions of organelle DNA with the polymerase chain reaction (PCR) and then using restriction enzymes to detect sequence variation (Arnold et al. 1992, McCauley 1994). Although chloroplast DNA has been reported to be maternally inherited in most flowering plants (Sears 1980, Birky 1988, Corriveau and Coleman 1988) and mitochondrial DNA has been shown to be maternally inherited in some genera of conifers (Wagner et al. 1987, Neale and Sederoff 1989, Sutton et al. 1991, Dong and Wagner 1993, 1994), these modes of transmission should be verified experimentally (Milligan 1992). Such tests often confirm maternal inheritance (e.g., Sutton et al. 1991), but low frequencies of biparental transmission have also been noted (Sears 1980, Wagner et al. 1991, Cruzan et al. 1993).

Low levels of intraspecific sequence variation in chloroplast genomes of flowering plants has limited the use of cpDNA markers for the study of population processes. Differences in cpDNA among populations has been found over relatively broad geographic ranges (Banks and Birky 1985, Fenster and Ritland 1992, Kim et al. 1992), but this type of variation may be of limited utility for population studies. Variation in maternally inherited markers in conifers and angiosperms has been used to examine levels of intraspecific genetic differentiation in a few cases (Milligan 1991, Ennos 1994, McCauley 1994). Development of markers based on 
more variable regions of the chloroplast genome (e.g., Taberlet et al. 1991, McCauley 1994) may make these techniques more accessible for analyses of dispersal and breeding system effects on the distribution of intraspecific genetic variation in plants. Interspecific variation in organelle genomes is more commonly found (Whittemore and Schaal 1991, Fenster and Ritland 1992, Kim et al. 1992, Dong and Wagner 1993), allowing separation of pollen and seed dispersal effects on the exchange of genetic material between species (Arnold et al. 1991, 1992, Rieseberg et al. 1991, Sutton et al. 1991).

\section{Studies of Hybrid Populations}

Natural hybridization is an important force affecting the evolution and ecology of plant populations. Cases of hybridization appear to be relatively frequent in plants (Knobloch 1972), and it has been estimated that the majority of extant taxa have been influenced by hybridization at some point in their history (Grant 1981, Whitham et al. 1991). Some authors have proposed that hybridization is a transient phenomenon, ultimately resulting in either fusion of two species or reinforcement of reproductive barriers and speciation (Wilson 1965, Remington 1968). More recently, some hybrid zones have been recognized as relatively stable features (i.e., over hundreds or thousands of generations: reviewed in Harrison 1990), and this observation has led to the proposal of a number of models to explain their persistence (reviewed in Arnold 1992, Rieseberg and Wendel 1993).

Hybrid zones can be maintained by frequent dispersal of parental genotypes into areas of hybridization where interspecific mating produces genotypes with reduced viability (tension zones: Key 1968, Barton and Hewitt 1985). Other models of hybrid zone maintenance include a greater role of ecological factors, with hybrids occurring in intermediate habitats along an environmental gradient (Endler 1977), or where a patchy distribution of habitats brings interfertile species into close contact (mosaic hybrid zones: Rand and Harrison 1989). Hybrid genotypes may have superior fitness in specific habitats (bounded hybrid superiority: Moore 1977, Moore and Buchanan 1985), or may be able to survive only in areas that have experienced natural or anthropogenic disturbances (Anderson 1948). Assessment of the contribution of these ecological and dispersal processes to the maintenance and structure of hybrid zones has become more feasible through the use of allozyme and DNA-based genetic markers.

Genetic markers have contributed to the study of interspecific hybridization by: (1) allowing unequivocal identification of hybrid individuals, (2) producing an assessment of the proportional contribution of parental genomes, and (3) providing a means of inferring patterns of selection and mating across regions of hybridization and within hybrid populations. Markers that are diagnostic for parental species can be assayed across a region of interspecific contact and putative hybridization to provide information about the extent and direction of introgression (i.e., exchange of genetic material: Heywood 1986, dePamphilis and Wyatt 1989, 1990, Nason et al. 1992, Hodges and Arnold 1994). With this approach, the strength of selection on different characters can be inferred by comparing rates of change in marker frequencies across the contact zone (Endler 1977, Hodges and Arnold 1994). While sampling across hybrid zones has contributed to our knowledge of patterns of introgression, understanding why hybrid zones persist requires population-level studies of mating and selection.

Genotypic distributions.-Different classes of hybrid genotypes can be identified by assaying individuals for genetic markers that are diagnostic for the parental species. By comparing the distribution of observed genotypes with expected distributions, the contributions of selection, dispersal, or assortative mating can be inferred (Barton and Hewitt 1985, Howard et al. 1993, Cruzan and Arnold 1994, Fig. 2). Some of these analyses have revealed associations between different genotypes and specific habitats (Alston and Turner 1963, Heiser et al. 1969, Heywood 1986, Cruzan and Arnold 1993, Hodges and Arnold 1994), differences in the relative viability of hybrid and parental genotypes (Keim et al. 1989, Cruzan and Arnold 1994), and patterns of assortative mating (Cruzan and Arnold 1994). Studies that combine genotypic classification with assessments of growth and survival at different life stages (Howard et al. 1993, Cruzan and Arnold 1994) hold considerable promise for elucidating processes that contribute to the evolution and maintenance of hybrid zones (Harrison 1990).

Cytonuclear disequilibria.-Analysis of disequilibria between molecular markers that are specific for cytoplasmic genomes and nuclear markers has provided a means of inferring processes of selection and assortative mating in hybrid populations (Asmussen et al. 1987, Forbes and Allendorf 1991, Paige et al. 1991, Cruzan and Arnold 1993, 1994; Fig. 3). Specific types of cytonuclear associations can be indicative of asymmetrical mating patterns (Asmussen et al. 1987, Paige et al. 1991, Cruzan and Arnold 1994), different levels of dispersal (Asmussen et al. 1989), or selection based on specific combinations of cytoplasmic haplotypes and nuclear genotypes (Asmussen et al. 1987, Paige et al. 1991, Cruzan and Arnold 1994; M. B. Cruzan and M. L. Arnold, unpublished data).

Although these statistical methods can be very powerful for describing patterns of genetic association within populations, they are most informative when combined with information on ecological aspects of the organism being studied (Asmussen et al. 1987). For example, while the patterns of cytonuclear association shown in Fig. 3 could be the result of a number of 


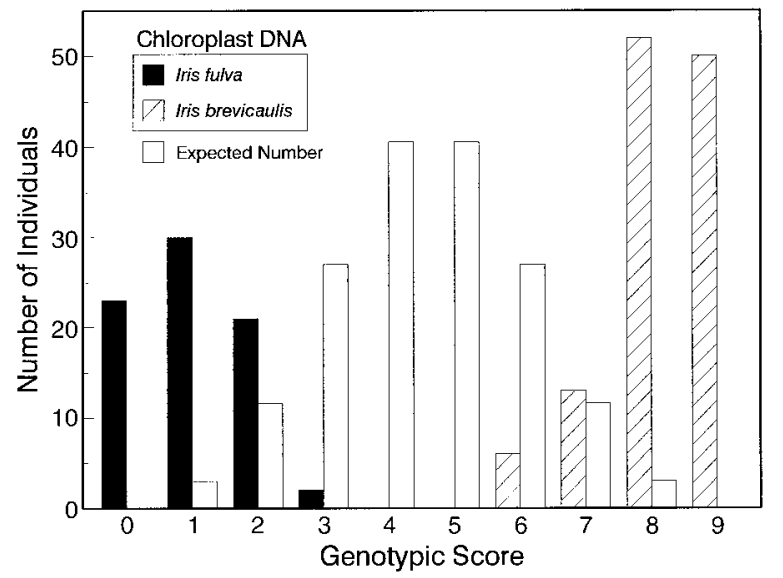

FIG. 2. Expected and observed genotypic distributions from an Iris hybrid population (data from Cruzan and Arnold 1993). The genotypic score is based on cpDNA and RAPD markers that are diagnostic for each species in allopatric populations. The expected distribution represents conditions of random mating, no selection, and no dispersal.

processes (selection, dispersal, or mating), Cruzan and Arnold $(1993,1994)$ were able to characterize patterns of environmental (genotypic-specific habitat associations) and intrinsic (embryo abortion) selection that contributed to homozygous disequilibria $\left(D_{1}\right.$ and $D_{3}$ : Fig. 3), and asymmetrical mating that contributed to the heterozygous disequilibrium $\left(D_{2}\right)$. These and other studies on Louisiana irises that have integrated field and laboratory techniques (e.g., Arnold et al. 1991, 1992, Carney et al. 1994) have provided a more thorough understanding of the factors responsible for the maintenance and structuring of hybrid populations.

\section{Future Directions}

Within the last decade there has been an explosion in the number of different types of genetic markers available (Arnheim et al. 1990, Hadrys et al. 1992, Avise 1994, Bachmann 1994) and in the number of statistical techniques developed for analyses of marker data (e.g., Asmussen et al. 1987, Epperson 1990, Weir 1990; Adams et al. 1992, Ritland 1996). There is often the perception that progress in the ecological application of genetic markers is driven by technological advances; however, a close examination of the field also reveals significant contributions through the adaptation of existing markers to novel situations (e.g., using allozyme variation to estimate heritability in the field: Ritland 1996, Ritland and Ritland 1996). In most cases the new DNA-based markers provide the same type of information as allozymes, but allow clearer resolution of genetic differences. The exceptions to this are the cytoplasmic markers (based on chloroplast or mitochondrial genomes), which can allow researchers to take advantage of their maternal mode of inheritance to examine the contribution of seed dispersal to gene flow (e.g., Arnold et al. 1992, McCauley 1994).

Many recent investigations in plant population biology have made an effort to combine genetic marker data with ecological information. This seems to reflect a general trend towards more studies of the mechanisms responsible for the development of patterns in populations. For example, floral manipulations (e.g., Carney et al. 1994, Leclerc-Potvin and Ritland 1994, Rieseberg et al. 1995, Cruzan and Barrett 1996), and correlative studies (e.g., Cruzan et al. 1994, Karron et al. 1995) have been used to identify specific mechanisms that control mating patterns. In other cases detailed spatial analyses of genetic structure have provided insights into the effects of dispersal and selection processes on genetic structure (e.g., Epperson 1990, Cruzan and Arnold 1993, Loiselle et al. 1995, Stacey et al. 1996). Integration of ecological and genetic data has provided a clearer understanding of the impact of ecological processes on the evolution of plant populations.

While one of the primary goals of ecological genetics has been the study of natural selection, up to now genetic markers have not been particularly useful in this endeavor. Allozyme markers have been used to study patterns of selection (Allard et al. 1972, Hamrick and Allard 1972, Clegg and Allard 1973; Clegg et al. 1978, Hamrick and Holden 1979), but this type of application has mostly been limited to highly inbred populations (Ennos 1990). Ultimately it would be desirable to examine genetic changes occurring at loci controlling particular morphological or physiological traits. Recent advances in mapping techniques with genetic markers developed for the improvement of breeding programs (Knapp et al. 1990, Lande and Thompson 1990) may

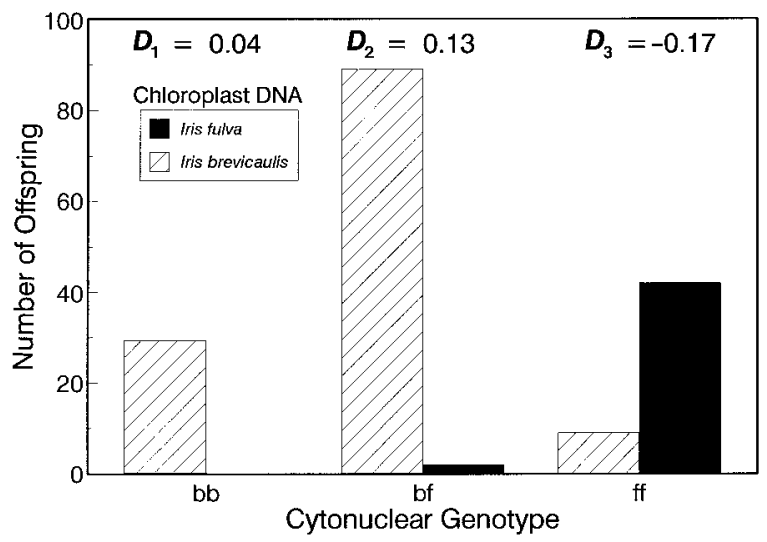

FIG. 3. Cytonuclear disequilibria estimates from seeds produced in an Iris hybrid population for a codominant marker locus and cpDNA markers (data from Cruzan and Arnold 1994). Disequilibria estimates (range from 0.00 to 0.25: Asmussen et al. 1987) indicate levels of association between cpDNA markers diagnostic for each species and homozygous $\left(D_{1}\right.$ and $\left.D_{3}\right)$ and heterozygous $\left(D_{2}\right)$ nuclear genotypes. Note that plants carrying I. brevicaulis cpDNA were maternal parents for nearly all of the heterozygous progeny produced. 
provide a means of analyzing selection on quantitative traits (Mitchell-Olds 1995). Genetic mapping of ecologically important traits has been conducted (e.g., Bradshaw et al. 1995, Mitchell-Olds 1996), and may provide an opportunity to examine the effects of selection under field conditions. Such novel combinations of field and laboratory studies inspired the development of the discipline of ecological genetics (Ford 1971). Continued integration of genetic marker techniques with field experiments will provide a wealth of information on evolutionary processes in plants.

\section{ACKNOWLEDGMENTS}

I thank M. L. Arnold, S. A. Hodges, A. J. McCaskill, and A. Snow for comments on the manuscript, and the Graduate School at the University of Tennessee for financial support.

\section{Literature Cited}

Adams, W. T., A. R. Griffin, and G. F. Moran. 1992. Using paternity analysis to measure effective pollen dispersal in plant populations. American Naturalist 140:762-780.

Aizen, M. A., K. B. Searcy, and D. L. Mulcahy. 1990. Among- and within-flower comparisons of pollen tube growth following self- and cross-pollinations in Dianthus chinensis (Caryophyllaceae). American Journal of Botany 77:671-678.

Allard, R. W., A. L. Kahler, and B. S. Weir. 1972. The effect of selection on esterase allozymes in a barley population. Genetics 73:489-503.

Alston, R. E., and B. L. Turner. 1963. Natural hybridization among four species of Baptisia (Leguminosae). American Journal of Botany 50:159-173.

Anderson, E. 1948. Hybridization of the habitat. Evolution 2:1-9.

Arnheim, N., T. White, and W. E. Rainey. 1990. Application of PCR: organismal and population biology. BioScience 40:174-182.

Arnold, M. L. 1992. Natural hybridization as an evolutionary process. Annual Review of Ecology and Systematics 23: 237-261.

Arnold, M. L., C. M. Buckner, and J. J. Robinson. 1991. Pollen-mediated introgression and hybrid speciation in Louisiana irises. Proceedings of the National Academy of Sciences (USA) 88:1398-1402.

Arnold, M. L., J. J. Robinson, C. M. Buckner, and B. D. Bennett. 1992. Pollen dispersal and interspecific gene flow in Louisiana irises. Heredity 68:399-404.

Asmussen, M. A., J. Arnold, and J. C. Avise. 1987. Definition and properties of disequilibrium statistics for associations between nuclear and cytoplasmic genotypes. Genetics 115:755-768.

Asmussen, M. A., J. Arnold, and J. C. Avise. 1989. The effects of assortative mating and migration on cytonuclear associations in hybrid zones. Genetics 122:923-934.

Avise, J. C. 1994. Molecular markers, natural history, and evolution. Chapman and Hall, New York, NY.

Bachmann, K. 1994. Molecular markers in plant ecology. New Phytologist 126:403-418.

Baker, A. M., and J. S. Shore. 1995. Pollen competition in Turnera ulmifolia (Turneraceae). American Journal of Botany 82:717-725.

Banks, J. A., and C. W. Birky, Jr. 1985. Chloroplast DNA diversity is low in a wild plant, Lupinus texensis. Proceedings of the National Academy of Sciences (USA) 82:69506954.

Barrett, S. C. H., A. H. D. Brown, and J. S. Shore. 1987. Disassortative mating in tristylous Eichhornia paniculata (Pontederiaceae). Heredity 58:49-55.
Barrett, S. C. H., and C. G. Eckert. 1990. Variation and evolution of mating systems in seed plants. Pages 229-254 in S. Kawano, editors. Biological approaches and evolutionary trends in plants. Academic Press, London, UK.

Barrett, S. C. H., and J. R. Kohn. 1991. Genetic and evolutionary consequences of small population size in plants: Implications for conservation. Pages 3-30 in D. A. Falk and K. E. Holsinger, editors. Genetics and conservation of rare plants. Oxford University Press, New York, New York, USA.

Barton, N. H., and G. M. Hewitt. 1985. Analysis of hybrid zones. Annual Review of Ecology and Systematics 16:113148.

Birky, C. W. 1988. Evolution and variation in plant chloroplast and mitochondrial genomes. Pages 23-55 in L. D. Gottlieb and S. K. Jain, editors. Plant evolutionary biology. Chapman and Hall, London, UK.

Bowman, R. N. 1987. Cryptic self-incompatibility and the breeding system of Clarkia unguiculata (Onagraceae). American Journal of Botany 74:471-476.

Bradshaw, H. D., S. M. Wilbert, K. G. Otto, and D. W. Schemske. 1995. Genetic mapping of floral traits associated with reproductive isolation in monkeyflowers (Mimulus). Nature 376:762-765.

Brookfield, J. F. Y. 1992. DNA fingerprinting in clonal organisms. Molecular Ecology 1:21-26.

Brown, A. H. D. 1979. Enzyme polymorphisms in plant populations. Theoretical Population Biology 15:1-42.

- 1990. Genetic characterization of plant mating systems. Pages 145-162 in A. H. D. Brown, M. T. Clegg, A. L. Kahler, and B. S. Weir, editors. Plant population genetics, breeding, and genetic resources. Sinauer, Sunderland, Massachusetts, USA.

Brown, B. A., and M. T. Clegg. 1984. Influence of flower color polymorphism on genetic transmission in a natural population of the common morning glory, Ipomoea purpurea. Evolution 38:796-803.

Broyles, S. B., and R. Wyatt. 1990. Paternity analysis in a natural population of Asclepias exaltata: multiple paternity, functional gender, and the "pollen donation hypothesis." Evolution 44:1454-1468.

Capossela, A., J. A. Silander, R. K. Jansen, B. Bergen, and D. R. Talbot. 1992. Nuclear ribosomal DNA variation among ramets and genets of white clover. Evolution 46: 1240-1247.

Carney, S. E., M. B. Cruzan, and M. L. Arnold. 1994. Reproductive interactions between hybridizing irises: analyses of pollen-tube growth and fertilization success. American Journal of Botany 81:1169-1175.

Casper, B. B. 1988. Evidence for selective embryo abortion in Cryptantha flava. American Naturalist 132:318-326.

Charlesworth, D., and B. Charlesworth. 1987. Inbreeding depression and its evolutionary consequences. Annual Review of Ecology and Systematics 18:237-268.

Clegg, M. T., and R. W. Allard. 1973. Viability versus fecundity selection in the slender wild oat, Avena barbata $\mathrm{L}$. Science 181:667-668.

Clegg, M. T., A. L. Kahler, and R. W. Allard. 1978. Genetic demography of plant populations. Pages 173-188 in P. F. Brussard, editors. Ecological genetics: the interface. Springer-Verlag, New York, New York, USA.

Corriveau, J. L., and A. W. Coleman. 1988. Rapid screening method to detect potential biparental inheritance of plastid DNA and results for over 200 angiosperm species. American Journal of Botany 75:1443-1458.

Crawford, T. J. 1984. What is a population? Pages 135-173 in B. Shorrocks, editor. Evolutionary ecology. British Ecological Society Symposium Number 23, Blackwell Scientific, Oxford, UK.

Cruzan, M. B. 1990a. Pollen-pollen and pollen-style inter- 
actions during pollen tube growth in Erythronium grandiflorum (Liliaceae). American Journal of Botany 77:116122 .

. $1990 \mathrm{~b}$. Variation in pollen size, fertilization ability, and postfertilization siring ability in Erythronium grandiflorum. Evolution 44:843-856.

Cruzan, M. B., and M. L. Arnold. 1993. Ecological and genetic associations in an Iris hybrid zone. Evolution 47: 1432-1445.

Cruzan, M. B., and M. L. Arnold. 1994. Assortative mating and natural selection in an Iris hybrid zone. Evolution 48 1946-1958.

Cruzan, M. B., M. L. Arnold, S. E. Carney, and K. R. Wollenberg. 1993. cpDNA inheritance in interspecific crosses and evolutionary inference in Louisiana irises. American Journal of Botany 80:344-350.

Cruzan, M. B., and S. C. H. Barrett. 1993. Contribution of cryptic incompatibility to the mating system of Eichhornia paniculata (Pontederiaceae). Evolution 47:925-934.

Cruzan, M. B., and S. C. H. Barrett. 1996. Post-pollination mechanisms influencing mating patterns and fecundity: an example from Eichhornia paniculata. American Naturalist 147:576-598.

Cruzan, M. B., J. L. Hamrick, M. L. Arnold, and B. D. Bennett. 1994. Mating system variation in hybridizing irises effects of phenology and floral densities on family outcrossing rates. Heredity 72:95-105.

Davis, S. K., J. E. Strassmann, C. Hughes, L. S. Pletscher, and A. R. Templeton. 1990. Population structure and kinship in Polistes (Hymenoptera, Vespidae): an analysis using ribosomal DNA and protein electrophoresis. Evolution 44: 1242-1254.

Dawson, I. K., K. J. Chalmers, R. Waugh, and W. Powell. 1993. Detection and analysis of genetic variation in Hordeum spontaneum populations from Israel using RAPD markers. Molecular Ecology 2:151-159.

dePamphilis, C. W., and R. Wyatt. 1989. Hybridization and introgression in buckeyes (Aesculus: Hippocastanaceae): a review of the evidence and a hypothesis to explain longdistance gene flow. Systematic Botany 14:593-611.

dePamphilis, C. W., and R. Wyatt. 1990. Electrophoretic confirmation of interspecific hybridization in Aesculus (Hippocastanaceae) and the genetic structure of a broad hybrid zone. Evolution 44:1295-1317.

Devlin, B., J. Clegg, and N. C. Ellstrand. 1992. The effect of flower production on male reproductive success in wild radish populations. Evolution 46:1030-1042.

Devlin, B., and N. C. Ellstrand. 1990. Male and female fertility variation in wild radish, an hermaphrodite. American Naturalist 136:86-107.

Devlin, B., K. Roeder, and N. C. Ellstrand. 1988. Fractional paternity assignment: theoretical development and comparison to other methods. Theoretical and Applied Genetics 76:369-380.

Dong, J., and D. B. Wagner. 1993. Taxonomic and population differentiation of mitochondrial diversity in Pinus banksiana and Pinus contorta. Theoretical and Applied Genetics 86:573-578.

Dong, J., and D. B. Wagner. 1994. Paternally inherited chloroplast polymorphism in Pinus: estimation of diversity and population subdivision, and tests of disequilibrium with a maternally inherited mitochondrial polymorphism. Genetics 136:1187-1194.

Ellstrand, N. C., and K. W. Foster. 1983. Impact of population structure on the apparent outcrossing rate of grain sorghum (Sorghum bicolor). Theoretical and Applied Genetics 66:323-327.

Ellstrand, N. C., and M. L. Roose. 1987. Patterns of genotypic diversity in clonal plant species. American Journal of Botany 74:123-131.
Endler, J. A. 1977. Geographic variation, speciation, and clines. Princeton University Press, Princeton, New Jersey, USA.

Ennos, R. A. 1990. Detection and measurement of selection: genetic and ecological approaches. Pages 200-214 in A. H. D. Brown, M. T. Clegg, A. L. Kahler, and B. S. Weir, editors. Plant population genetics, breeding, and genetic resources. Sinauer, Sunderland, Massachusetts, USA.

- 1994. Estimating the relative rates of pollen and seed migration among plant populations. Heredity 72:250259.

Ennos, R. A., and M. T. Clegg. 1982. Effect of population substructuring on estimates of outcrossing rate in plant populations. Heredity 48:283-292.

Epling, C., and T. Dobzhansky. 1942. Genetics of natural populations. VI. Microgeographic races in Linanthus parryae. Genetics 27:317-332.

Epperson, B. K. 1990. Spatial patterns of genetic variation within plant populations. Pages 229-253 in A. H. D. Brown, M. T. Clegg, A. L. Kahler, and B. S. Weir, editors. Plant population genetics, breeding, and genetic resources. Sinauer, Sunderland, Massachusetts, USA.

Epperson, B. K., and M. T. Clegg. 1987. First-pollen primacy and pollen selection in the morning glory, Ipomoea purpurea. Heredity 58:5-14.

Fabergé, A. C. 1943. Genetics of the scapiflora section of Papaver. II. The alpine poppy. Journal of Genetics 45:139170.

Falconer, D. S. 1981. Introduction to quantitative genetics. Longman, London, UK.

Farris, M. A., and J. B. Mitton. 1984. Population density, outcrossing rate, and heterozygosity superiority in ponderosa pine. Evolution 38:1151-1154.

Fenster, C. B., and K. Ritland. 1992. Chloroplast DNA and isozyme diversity in two Mimulus species (Scrophulariaceae) with contrasting mating systems. American Journal of Botany 79:1440-1447.

Forbes, S. H., and F. W. Allendorf. 1991. Associations between mitochondrial and nuclear genotypes in cutthroat trout hybrid swarms. Evolution 45:1332-1349.

Ford, E. B. 1971. Ecological genetics. Metheun, London, UK.

Fritsch, P., and L. Rieseberg. 1992. High outcrossing rates maintain male and hermaphrodite individuals in populations of the flowering plant Datisca glomerata. Nature 359: 633-636.

Fryxell, P. A. 1957. Mode of reproduction in higher plants. Botanical Review 23:135-233.

Fyfe, J. L., and N. T. J. Bailey. 1951. Plant breeding studies in leguminous forage crops. I. Natural cross-breeding in winter beans. Journal of Agricultural Science 41:371-378.

Grant, V. 1981. Plant speciation. Second edition. Columbia University Press, New York, New York, USA.

Hadrys, H., M. Balick, and B. Schierwater. 1992. Applications of random amplified polymorphic DNA (RAPD) in molecular ecology. Molecular Ecology 1:55-63.

Hamrick, J. L., and R. W. Allard. 1972. Microgeographic variation in allozyme frequencies in Avena barbata. Proceedings of the National Academy of Sciences (USA) 69: 2100-2104.

Hamrick, J. L., and M. J. W. Godt. 1990. Allozyme diversity in plant species. Pages 43-63 in A. H. D. Brown, M. T. Clegg, A. L. Kahler, and B. S. Weir, editors. Plant population genetics, breeding, and genetic resources. Sinauer, Sunderland, Massachusetts USA.

Hamrick, J. L., and L. R. Holden. 1979. Influence of microhabitat heterogeneity on gene frequency distribution and gamete phase disequilibrium in Avena barbata. Evolution 33:521-533.

Hamrick, J. L., Y. B. Linhart, and J. B. Mitton. 1979. Re- 
lationships between life history characteristics and electrophoretically-detectable genetic variation in plants. Annual Review of Ecology and Systematics 10:173-200.

Harding, J., C. B. Mankenen, and M. Elliot. 1974. Genetics of Lupinus. VII. Outcrossing, autofertility, and variability in natural populations of the Nanus group. Taxon 23:729738 .

Harrison, R. G. 1990. Hybrid zones: windows on evolutionary process. Oxford Survey of Evolutionary Biology 7:69128.

Heiser, C. B., S. B. Smith, S. B. Clevenger, and W. C. Martin, Jr. 1969. The North American sunflowers (Helianthus). Memoirs of the Torrey Botanical Club 22:1-218.

Heywood, J. S. 1986. Clinal variation associated with edaphic ecotones in hybrid populations of Gallardia pulchella. Evolution 40:1132-1140.

Hodges, S. A., and M. L. Arnold. 1994. Floral and ecological isolation between Aquilegia formosa and Aquilegia pubescens. Proceedings of the National Academy of Sciences (USA) 91:2493-2496.

Holsinger, K. E. 1991. Mass-action models of plant mating systems: the evolutionary stability of mixed mating systems. American Naturalist 138:606-622.

Hong, Y. P., V. D. Hipkins, and S. H. Strauss. 1993. Chloroplast DNA diversity among trees, populations and species in the California closed-cone pines (Pinus radiata, Pinus muricata and Pinus attenuata). Genetics 135:1187-1196.

Horovitz, A., and J. Harding. 1972. Genetics of Lupinus. V. Intraspecific variability for reproductive traits in Lupinus nanus. Botanical Gazette 133:155-165.

Howard, D. J., G. L. Waring, C. A. Tibbets, and P. G. Gregory. 1993. Survival of hybrids in a mosaic hybrid zone. Evolution 47:789-800.

Hsian, J. Y., and L. H. Rieseberg. 1994. Population genetic structure of Yushania niitakayamensis (Bambusoidea, Poaceae) in Taiwan. Molecular Ecology 3:201-208.

Humphreys, M. O., and J. S. Gale. 1974. Variation in wild populations of Papaver dubium. VIII. The mating system. Heredity 33:33-41.

Hunt, G., and R. Page. 1992. Patterns of inheritance with RAPD molecular markers reveal novel types of polymorphism in the honey bee. Theoretical and Applied Genetics 85: $15-20$.

Husband, B., and D. W. Schemske. 1996. Evolution of the magnitude and timing of inbreeding depression in plants. Evolution 50:54-70.

Johnston, M. O. 1993. Tests of two hypotheses concerning pollen competition in a self-compatible, long-styled species (Lobelia cardinalis: Lobeliaceae). American Journal of Botany 80:1400-1406.

Jones, K. N. 1994. Nonrandom mating in Clarkia gracilis (Onagraceae): a case of cryptic self-incompatibility. American Journal of Botany 81:195-198.

Karron, J. D., N. N. Thumser, R. Tucker, and A. J. Hessenauer. 1995. The influence of population density on outcrossing rates in Mimulus ringens. Heredity 75:175-180.

Keim, P., K. N. Paige, T. G. Whitham, and K. G. Lark. 1989. Genetic analysis of an interspecific hybrid swarm of Populus: occurrence of unidirectional introgression. Genetics 123:557-565.

Key, K. H. L. 1968. The concept of stasipatric speciation. Systematic Zoology 17:14-22.

Kim, K. J., R. K. Jansen, and B. L. Turner. 1992. Evolutionary implications of intraspecific DNA variation in dwarf dandelions (Krigia: Asteraceae). American Journal of Botany 79:708-715.

King, L. M., and B. A. Schaal. 1989. Ribosomal-DNA variation and distribution in Rudbeckia missouriensis. Evolution 43:1117-1119.

Knapp, S. J., W. C. Bridges, and D. Birkes. 1990. Mapping quantitative trait loci using molecular marker linkage maps. Theoretical and Applied Genetics 79:583-592.

Knobloch, I. W. 1972. Intergeneric hybridization in flowering plants. Taxon 21:97-103.

Kohn, J. R., and S. C. H. Barrett. 1992a. Experimental studies on the functional significance of heterostyly. Evolution 46:43-55.

Kohn, J. R., and S. C. H. Barrett. 1992b. Floral manipulations reveal the cause of male fitness variation in experimental populations of Eichhornia paniculata (Pontederiaceae). Functional Ecology 6:590-595.

Lande, R., D. W. Schemske, and S. T. Schultz. 1994. High inbreeding depression, selective interference among loci, and the threshold selfing rate for purging recessive lethal mutations. Evolution 48:965-978.

Lande, R., and R. Thompson. 1990. Efficiency of markerassisted selection in the improvement of quantitative traits. Genetics 124:743-756.

Learn, G. H., and B. A. Schaal. 1987. Population subdivision for ribosomal DNA repeat variants in Clematis fremontii. Evolution 41:433-438.

Leclerc-Potvin, C., and K. Ritland. 1994. Modes of selffertilization in Mimulus guttatus (Scrophulariaceae): a field experiment. American Journal of Botany 81:199-205.

Lloyd, D. G. 1979. Some reproductive factors affecting the selection of self-fertilization in plants. American Naturalist 113:67-79.

. 1992. Self- and cross-fertilization in plants. II. The selection of self-fertilization. International Journal of Plant Science 153:370-380.

Lloyd, D. G., and D. J. Schoen. 1992. Self- and cross-fertilization in plants. I. Functional dimensions. International Journal of Plant Science 153:358-369.

Loiselle, B. A., V. I. Sork, J. L. Nason, and C. Graham. 1995. Spatial genetic structure of a tropical understory shrub, Psychotria officinalis (Rubiaceae). American Journal of Botany 82:1420-1425.

Loveless, M. D., and J. L. Hamrick. 1984. Ecological determinants of genetic structure in plant populations. Annual Review of Ecology and Systematics 15:65-95.

Lynch, M., and B. G. Milligan. 1994. Analysis of population genetic structure with RAPD markers. Molecular Ecology 3:91-99.

Marshall, D. L., and M. W. Folsom. 1992. Mechanisms of nonrandom mating in wild radish. Pages 91-118 in R. Wyatt, editor. Ecology and evolution of plant reproduction, new approaches. Chapman and Hall, New York, New York, USA.

Mashburn, S. J., R. R. Sharitz, and M. H. Smith. 1978. Genetic variation among Typha populations of the southeastern United States. Evolution 32:681-685.

McCauley, D. E. 1994. Contrasting the distribution of chloroplast DNA and allozyme polymorphism among local populations of Silene alba: implications for studies of gene flow in plants. Proceedings of the National Academy of Sciences (USA) 91:8127-8131.

Meagher, T. R. 1986. Analysis of paternity within a natural population of Chamaelirium luteum I. Identification of most-likely parents. American Naturalist 128:199-215.

Milligan, B. G. 1991. Chloroplast DNA diversity within and among populations of Trifolium pratense. Current Genetics 19:411-416.

1992. Is organelle DNA strictly maternally inherited? Power analysis of a binomial distribution. American Journal of Botany 79:1325-1328.

Mitchell-Olds, T. 1995. The molecular basis of quantitative genetic variation in natural populations. Trends in Ecology and Evolution 10:324-328.

1996. Genetic constraints on life-history evolution: 
Quantitative-trait loci influencing growth and flowering in Arabidopsis thaliana. Evolution 50:140-145.

Montalvo, A. M. 1992. Relative success of self and outcross pollen comparing mixed- and single-donor pollinations in Aquilegia caerulea. Evolution 46:1181-1198.

Moore, W. S. 1977. An evaluation of narrow hybrid zones in vertebrates. Quarterly Review of Biology 52:263-277.

Moore, W. S., and D. B. Buchanan. 1985. Stability of the northern flicker hybrid zone in historical times: implications for adaptive speciation theory. Evolution 39:135-151.

Morgan, M. T., and S. C. H. Barrett. 1990. Outcrossing rates and correlated mating within a population of Eichhornia paniculata (Pontederiaceae). Heredity 64:271-280.

Motten, A. F., and J. Antonovics. 1992. Determinants of outcrossing rate in a predominantly self-fertilizing weed, Datura stramonium (Solanaceae). American Journal of Botany 79:419-427.

Nason, J. D., N. C. Ellstrand, and M. L. Arnold. 1992. Patterns of hybridization and introgression in populations of oaks, manzanitas, and irises. American Journal of Botany 79:101-111.

Neale, D. B., and R. R. Sederoff. 1989. Paternal inheritance of chloroplast DNA and maternal inheritance of mitochondrial DNA in loblolly pine. Theoretical and AppliedGenetics 77:212-216.

Nei, M. 1975. Molecular population genetics and evolution. North Holland, Amsterdam.

Nevo, E., A. Beiles, and R. Ben-Shlomi. 1984. The evolutionary significance of genetic diversity: Ecological, demographic, and life history correlates. Pages 13-213 in G. S. Mani, editor. Evolutionary dynamics of genetic diversity. Springer-Verlag, New York, New York, USA.

Nybom, H., S. H. Rogstad, and B. A. Schaal. 1990. Genetic variation detected by use of the M13 "DNA fingerprint" probe in Malus, Prunus, and Rubus (Rosaceae). Theoretical and Applied Genetics 79:153-156.

Nybom, H., and B. A. Schaal. 1990. DNA "fingerprints" applied to paternity analysis in apples (Malus x domestica). Theoretical and Applied Genetics 79:763-768.

Paige, K. N., W. C. Capman, and P. Jennetten. 1991. Mitochondrial inheritance patterns across a cottonwood hybrid zone: Cytonuclear disequilibria and hybrid zone dynamics. Evolution 45:1360-1369.

Pfahler, P. L. 1967. Fertilization ability of maize pollen grains. II. Pollen genotype, female sporophyte and pollen storage interactions. Genetics 37:513-521.

Piper, J. G., B. Charlesworth, and D. Charlesworth. 1986 Breeding system evolution in Primula vulgaris and the role of reproductive assurance. Heredity 56:207-217.

Poethig, R. S. 1987. Clonal analysis of cell lineage patterns in plant development. American Journal of Botany 74:581594

Rand, D. M., and R. G. Harrison. 1989. Ecological genetics of a mosaic hybrid zone: mitochondrial, nuclear, and reproductive differentiation of crickets by soil type. Evolution 43:432-449.

Remington, C. L. 1968. Suture zones of hybrid interaction between recently joined biotas. Evolutionary Biology 2: 321-328.

Rick, C. M., M. Holle, and R. W. Thorp. 1978. Rates of cross-pollination in Lycopersicon pimpinellifolium: impact of genetic variation in floral characters. Plant Systematics and Evolution 129:31-44.

Rieseberg, L. H., H. C. Choi, and D. Ham. 1991. Differential cytoplasmic versus nuclear introgression in Helianthus. Journal of Heredity 82:489-493.

Rieseberg, L. H., A. M. Desrochers, and S. J. Youn. 1995. Interspecific pollen competition as a reproductive barrier between sympatric species of Helianthus (Asteraceae) American Journal of Botany 82:515-519.
Rieseberg, L. H., and J. F. Wendel. 1993. Introgression and its consequences in plants. Pages 70-114 in R. G. Harrison, editor. Hybrid zones and the evolutionary process. Oxford University Press, Oxford, UK.

Rigney, L. P. 1995. Post-fertilization causes of differential success of pollen donors in Erythronium grandiflorum (Liliaceae): nonrandom ovule abortion. American Journal of Botany 82:578-584.

Rigney, L. P., J. D. Thomson, M. B. Cruzan, and J. Brunet. 1993. Differential success of pollen donors in a self-compatible lily. Evolution 47:915-924.

Ritland, K. 1984. The effective proportion of self-fertilization with consanguineous matings in inbred populations. Genetics 106: $139-152$.

- 1989. Correlated matings in the partial selfer Mimulus guttatus. Evolution 43:848-859.

- 1990. A series of FORTRAN computer programs for estimating plant mating systems. Journal of Heredity 81:235-237.

_.. 1996. A marker-based method for inferences about quantitative inheritance in natural populations. Evolution 50:1062-1073.

Ritland, K., and F. R. Ganders. 1985. Variation in the mating system of Bidens menziesii (Asteraceae) in relation to population substructure. Heredity 55:235-244.

Ritland, K., and S. Jain. 1981. A model for the estimation of outcrossing rate and gene frequencies using $\mathrm{n}$ independent loci. Heredity 47:35-52.

Ritland, K., and C. Ritland. 1996. Inferences about quantitative inheritance based upon population structure in the common yellow monkeyflower, Mimulus guttatus. Evolution 50:1074-1082.

Rogstad, S. H., H. Nybom, and B. A. Schaal. 1991a. The tetrapod "DNA fingerprinting" M13 repeat probe reveals genetic diversity and clonal growth in quaking aspen (Populus tremuloides, Salicaceae). Plant Systematics and Evolution 175: 115-123.

Rogstad, S. H., K. Wolff, and B. A. Schaal. 1991b. Clonal structure and genetic variation in Asimina triloba Dunal (Annonaceae) revealed by the M13 "DNA fingerprinting" probe. American Journal of Botany 78:1391-1396.

Russell, J. R., J. Hosein, E. Johnson, R. Waugh, and W. Powell. 1993. Genetic differentiation of cocoa (Theobroma cocoa L.) populations revealed by RAPD analysis. Molecular Ecology 2:89-97.

Schaal, B. A. 1987. Somatic variation and genetic structure in plant populations. Pages 47-58 in A. J. Davy, M. J. Hutchings, and A. R. Watkinson, editors. Plant population ecology. Blackwell Scientific, London, UK.

Schaal, B., and G. H. Learn. 1988. Ribosomal DNA variation within and among plant populations. Annals of the Missouri Botanical Garden 75:1207-1216.

Schemske, D. W., and R. L. Lande. 1985. The evolution of self-fertilization and inbreeding depression in plants. II. Empirical observations. Evolution 39:41-52.

Schoen, D. J. 1982. Genetic variation and the breeding system of Gilia achilleifolia. Evolution 36:361-370.

- 1988. Mating system estimation via the one pollen parent model with the progeny array as the unit of observation. Heredity 60:439-444.

Schoen, D. J., and D. G. Lloyd. 1992. Self- and cross-fertilization in plants. III. Methods for studying modes and functional aspects of self-fertilization. International Journal of Plant Sciences 153:381-393.

Schoen, D. J., and S. C. Stewart. 1987. Variation in male fertilities and pairwise mating probabilities in Picea glauca. Genetics 116:141-152.

Sears, B. B. 1980. Elimination of plastids during spermatogenesis and fertilization in the plant kingdom. Plasmid 4: 233-255. 
Smyth, C. A., and J. L. Hamrick. 1984. Variation in estimates of outcrossing in musk thistle populations. Journal of Heredity 75:303-307.

Snow, A. A., and P. O. Lewis. 1993. Reproductive traits and male fertility in plants: empirical approaches. Annual Review of Ecology and Systematics 24:331-351.

Snow, A. A., and T. P. Spira. 1991. Differential pollen-tube growth rates and nonrandom fertilization in Hibiscus moscheutos (Malvaceae). American Journal of Botany 78: 1419-1426.

Snow, A. A., and T. P. Spira. 1993. Individual variation in the vigor of self pollen and selfed progeny in Hibiscus moscheutos (Malvaceae). American Journal of Botany 80: $160-164$.

Stacey, E. A., J. D. Nason, S. P. Hubbell, R. B. Foster, and R. Condit. 1996. Pollen dispersal in low-density populations of 3 neotropical trees. American Naturalist 148:275298.

Sutton, B. C. S., D. J. Flanagan, J. R. Gawley, C. H. Newton, D. T. Lester, and Y. A. El-Kassaby. 1991. Inheritance of chloroplast and mitochondrial DNA in Picea and composition of hybrids from introgression zones. Theoretical and Applied Genetics 82:242-248.

Taberlet, P., L. Gielly, G. Pautou, and J. Bouvet. 1991. Universal primers for amplification of three non-coding regions of chloroplast DNA. Plant Molecular Biology 17:11051109.

Thomson, J. D., and R. C. Plowright. 1980. Pollen carryover, nectar rewards, and pollinator behavior with special reference to Diervilla Ionicera. Oecologia 46:68-74.

Thomson, J. D., M. V. Price, N. M. Waser, and D. A. Stratton. 1986. Comparative studies of pollen and fluorescent dye transport by bumble bees visiting Erythronium grandiflorum. Oecologia 69:561-566.

Thomson, J. D., and D. A. Stratton. 1985. Floral morphology and cross-pollination in Erythronium grandiflorum (Liliaceae). American Journal of Botany 72:433-437.

Thomson, J. D., and B. A. Thomson. 1989. Dispersal of Erythronium grandiflorum pollen by bumblebees: Implications for gene flow and reproductive success. Evolution 43:657-661.

Uyenoyama, M. K., K. E. Holsinger, and D. M. Waller. 1993. Ecological and genetic factors directing the evolution of self-fertilization. Oxford Surveys in Evolutionary Biology 9:327-381.

Vasek, F. C. 1964. Outcrossing in natural populations. I. The Breckinridge Mountain population of Clarkia exilis. Evolution 18:213-218.
Vasek, F. C., and J. Harding. 1976. Outcrossing in natural populations. V. Analysis of outcrossing, inbreeding, and selection in Clarkia exilis and Clarkia temblorensis. Evolution 30:403-411.

Wagner, D. B., J. Dong, M. R. Carlson, and A. D. Yanchuk. 1991. Paternal leakage of mitochondrial DNA in Pinus. Theoretical and Applied Genetics 82:510-514.

Wagner, D. B., G. R. Furnier, M. A. Saghai-Marooe, S. M. Williams, B. P. Dancik, and R. W. Allard. 1987. Chloroplast DNA polymorphisms in lodgepole and jack pines and their hybrids. Proceedings of the National Academy of Sciences (USA) 84:2097-2100.

Waser, N. M., and M. V. Price. 1982. A comparison of pollen and fluorescent dye carry-over by natural pollinators of Ipomopsis aggregata (Polemoniaceae). Ecology 63:11681172.

Weir, B. S. 1990. Genetic data analysis: methods for discrete population genetic data. Sinauer, Sunderland, Massachusetts, USA.

Weller, S. G., and R. Ornduff. 1977. Cryptic self-incompatibility in Amsinckia grandiflora. Evolution 31:47-51.

Whitham, T. G., P. A. Morrow, and B. M. Potts. 1991. Conservation of hybrid plants. Science 254:779-780.

Whittemore, A. T., and B. A. Schaal. 1991. Interspecific gene flow in sympatric oaks. Proceedings of the National Academy of Sciences, (USA) 88:2450-2544.

Wiens, D., C. Calvin, C. Wilson, C. Davern, D. Frank, and S. Seavey. 1987. Reproductive success, spontaneous embryo abortion, and genetic load in flowering plants. Oecologia 71:501-509.

Wilde, J., R. Waugh, and W. Powell. 1992. Genetic fingerprinting of Theobroma clones using randomly amplified polymorphic DNA markers. Theoretical and Applied Genetics 83:871-877.

Wilson, E. O. 1965. The challenge from related species. Pages 7-27 in H. G. Baker and G. L. Stebbins, editors. The genetics of colonizing species. Academic Press, New York, New York, USA.

Wolff, K., B. Friso, and J. M. M. van Damme. 1988. Outcrossing rates and male sterility in natural populations of Plantago coronopus. Theoretical and Applied Genetics 76: 190-196.

Wolff, K., S. H. Rogstad, and B. A. Schaal. 1994. Population and species variation of minisatellite DNA in Plantago. Theoretical and Applied Genetics 87:733-740.

Wright, S. 1978. Evolution and genetics of populations. Volume 4. Variability within and among natural populations. University of Chicago Press, Chicago, Illinois, USA. 